\title{
DISCURSO DE PARANINFO
}

pronunciado por ocasião da colação de grau dos licenciandos de 1957, da Faculdade de Filosofia da U. do P., aos 14 de dezembro, no anfiteatro do Colégio Estadual do Paraná.

PROF. DR. HOMERO BATISTA DE BARROS

Meus diletos paraninfados:

Ao imperativo do vosso convite que tanto me desvaneceu e que ficará indelével no meu coração, aqui estou a trazer-vos uma mensagem de esperança, pois não sei do que melhor se ajuste às vibrações da mocidade do que a esperança que é prenúncio de vitória.

As láureas que recebestes estão a empolgar-vos de justa ufania nas galas desta noite excepcional. O Corpo Docente, que vos dirigiu os passos com alta sabedoria e grande senso de responsabilidade, exulta com as vossas alegres emoções da altitude a que ascendentes. Sinto que a antevisão do futuro, exaltando as energias da vossa alma juvenil, se esboça nesta aivorada risonha de sonhos com que ides começar a grande jornada. Estais vivendo uma das melhores páginas da vossa vida. Vossas casas em festa celebram as vossas conquistas tão justamente merecidas. E a vossa Faculdade de Filosofia, que também é a vossa casa, compartilha do sabor do triunfo que perpassou a sensibilidade dos vossos anseios, ao receberdes o galardão de tantos trabalhos. Dir-se-ia um dia de glória na crono ogia da Universidade.

Realmente o é. Mas não vos iludais. Antes, alegrai-vos no Senhor, que só a Ele, de quem tudo é participação, é que devemos render a honra e a glória do quanto sois e do quanto sejais, 
pois como disse o Apóstolo, nada tendes que não tenhais recebido.

Tudo tem origem no Criador de tôdas as coisas, fonte imperecível e fecunda do amor, da verdade, da beleza, harmonia. Louvemos todos a Deus Onipotente pela felicidade que vos sorri ao dealbar da vida pública.

Deixais os bancos acadêmicos precisamente quando a $\mathrm{Fa}$ culdade se reveste da imponência de novas edificações, equipada, moderna, eficiente, graças ao dinamismo singular do seu preeminente Reitor Magnífico. Prof. Dr. Flávio Suplici de Lacerda, que teve o arrôjo administrativo de realizar, para servir à $\mathrm{Na}$ ção, urna obra perene e monumental de irradiantes benefícios.

O reconhecimento que a cultura nacional ficará devendo a êsse homem público de tão largo dscortino dos problemas universitários, se já é imenso na admiração que a sociedade tributa ao seu poder construtivo, será ainda mais dilatado aos olhos serenos da posteridade, que aquilatará do nível cultural dos nossos mestres ao defrontar o gigantismo dessas obras immorredoiras em que se alicerça também a civilização de um povo.

$O$ vosso afastamento pela contingência da formatura não importa numa dissociação. Não é uma solução de continuidade em vossa vida universitária. $E$ bem avisado dessa circunstância, o vosso Paraninfo entendi de não vos proferir uma oração de despedida, senão de esperança, na espectativa de que a vossa companhia na Associação de Antigos Alunos e em tantos misteres que a escola proporciona, vai permitir-nos a freqüência animadora da vossa colaboração, o contato periódico da vossa amizade, o entusiasmo da mesma faina a que vos habituastes, pois a $\mathrm{Fa}$ culdade não prescinde da presença dos moços de inteligência como não proscreve da sua egrégia Congregação os seus professôres jubilados.

A Universidade caminha aos passos largos da bravura intelectual e moral da mocidade. Creio mesmo que, por entre as incertezas do presente, nela residem as reservas mais estupendas de renovação nacional. $E$ quando essa bravura se reflete no 
e evado espírito ético e na pujança de propósitos com que falou a vossa fidalga intérprete, o que me emociona é a ufania de ter-vos ao lado, vibrando ao calor dos vossos ideais, sentindo arder a flama da vossa fé na pureza das instituições e na dignidade dos homens livres.

Daí o entender-se que, pórtico a dentro das Universidades. é que se forjam os esteios do humanismo cristão na estruturação duma mentalidade democrática em que se refugiam as liberdades ameaçadas pela nova ordem de regimes violentos $e$ desumanizadores.

Nem poderia ser diversamente. $E$ isso bem se denunciou nos sentimentos que inspiraram a palavra a que há pouco aplaudimcs. A oração dos moços há-de ser sempre assim, em alto estilo de sinceridade, com a franqueza que alguma vez se transforma em sal da terra, na eloquiência da crítica edificante, com tôda a aristocracia da inteligência, com tôdas as mostras da cultura com que se pronunciou essa flor do talento universitário que escolhestes para a tribuna.

As rebeldias da mocidade são providenciais. E se assim não ocorresse, a História da Pátria não estaria pontilhada de feitos heróicos marcados com a galhardia e o desassombro de g:rações que levaram por timbre o idealismo das. causas grandes e das epopéias inesqueciveis e que transformaram as Faculdades Jurídicas de $\mathrm{S}$. Paulo e do Recife no berço esplêndido em que o Brasil acordou para a marcha triunfal da sua democracia.

A carreira que elegestes, nobre e be ofício de ensinar, maneja com todo o saber que é dado a um homem culto, num campo imensurável de atividades, pois o magistério pertence à classe dos fenômenos sociológicos, talvez de todos o mais complexo pela transcendência em que paira, advindo da correlação dos múltiplos conhecimentos humanos e estando em função de todos os fenômenos em que se desdobra a natureza.

Êsse poder de influência que o magistério faculta, envolve responsabilidades de orientação das quais eu vos alerto para o dever precípuo de imprimir maior cunho de brasilidade nos quadros culturais. 
Sêde brasileiros com galhardia e profundo fervor patriótico.

A missāo do professor nacional não deve desnaturar-se sob o influxo dos mitos de nosso tempo, a ponto de se divorciar dos problemas gerais da Nação, para se entregar ao esfôrço inģlóris de estrangeirar as novas gerações, em aberto desajustamento com a índole, as tradições e a formação espiritual do Brasil.

Bem sabeis que o povo que vai conspurcando o seu idioma, relaxando a sua re'igiāo, esquecendo a sua história, desconhecendo a terra e entregando a alma ao enlêvo do folclore de outras gentes, é povo dominado e vencido, cuja nacionalidade so afrouxou e feneceu, comprometido que foi o princípio de unidade espiritual através do espaço físico e de continuidade idêntica através do tempo.

O traço forte das nossas origens lusitanas, florescidas às luzes do catolicismo e revigoradas pelas conquistas da inteligência e da cultura nacional não se desvia das suas nascentes ao capricho de correntes que se opõem ao nosso patrimônio histórico, às nossas tendências étnicas e às nossas aquisições morais no influir do tempo.

Sêde brasileiros, eu vos repito, com galhardia e a'tivez.

Para vós, que representais uma parcela nova e admirável do aparelhamento intelectual para difundir cultura e dilatar em mais alto grau a educação aos nossos patrícios, a vocação nacionalista se faz essencial, mas nacionalismo sadio que desencante 0 conhecimento da terra mater no seu passado, na sua base física, em sua potencialidade econômica, em seus problemas sociais, nacionalismo sem respeito humano, que ensine, pregue e proclame em tôdas as oportunidades a fé com que as nossas Mães nos ensinaram a louvar a Deus, nacionalismo sem preconceitos nem restrições na. defesa e na preservação do nosso organismo democrático, a começar pelo repúdio intransigente ao comunismo porque a sua ideologia não tem princípio algum que se adapte à estrutura social do Brasil.

O nacionalismo com que eu vos aceno há-de revelar a região desconhecida em que vivemos ao privilégio de uma natureza exuberante, marcada por cenários dantescos como o das 
Quedas do Iguaçu, onde a desordem do caos contrasta com o movimento fascinante de um mundo, ou pela riqueza alucinante das terras roxas a desafiarem a ambição humana para não vos falar em outros característicos sedutores do Paraná.

A Universidade expande ao descortino da terra e as turmas como a vossa, que por aqui passarem, levarão os olhos encantados ao penetrarem as suas populações, sentindo o Brasil palpitar nas virtudes de nossa gente simples, na sua psicologia, nas suas preciosas reservas que ainda constituem, mercê de Deus, a fôrça invencivel de resistência conservadora da honra, da dignidade e das virtudes morais da familia brasileira.

A nacionalização do ensino que vos preconizo, através de um conhecimento aberto a tôdas essas especulações, não se confunde com nenhum repúdio ao ambiente americano em que a Nação se acha integrada por laços indestrutiveis de uma política de fraternidade continental, voltada para a estruturação dos liames que unem os povos americanos, sob o senso das mesmas diretrizes de civilização cristã.

Dedicai-vos, que o Brasil precisa de vós. Sabei servi-lo, sem tergiversardes nos cuidados de todos os momentos que vos ele reclama e quando as fôrças do mal vos incitarem ao deslize, buscando enfraquecer-vos a pertinácia e o denodo na boa causa, rejeitai as seduções da tentação, escudados na vossa consciência. E crede que em tôda a vossa peregrinação pela vida não vos faltará, se não fraquejardes na fé que transpõe montanhas,' a proteção da excelsa padroeira da vossa querida Faculdade de Filosofia, a Virgem do Rosário do Carmo, que certa vez, por entre a piedosa atitude dos vossios mestres e dos vossos colegas, vos deixou a grande bênção protetora através da visita de sua sagrada Imagem.

E já não é dado ao Paraninfo continuar neste derradeiro convívio convosco. Ide, porque em vossos lares alguém anseia por estreitar-vos no demorado abraço do coração...

Sêde venturosos e felizes! 